\title{
Culture Method and PCR for the Detection of Helicobacter pylori in Drinking Water in Basrah Governorate Iraq
}

\author{
A. A. Al-Sulami, ${ }^{1}$ T. A. A. Al-Edani, ${ }^{2}$ and A. A. Al-Abdula ${ }^{2}$ \\ ${ }^{1}$ College of Education, University of Basrah, Ashar P.O. Box 2108, Ashar, Basrah, Iraq \\ ${ }^{2}$ Department of Biology, College of Sciences, University of Basrah, Ashar P.O. Box 2108, Ashar, Basrah, Iraq
}

Correspondence should be addressed to A. A. Al-Sulami, aminabdulah@yahoo.com

Received 8 January 2012; Revised 14 April 2012; Accepted 15 April 2012

Academic Editor: Ping-I Hsu

Copyright (C) 2012 A. A. Al-Sulami et al. This is an open access article distributed under the Creative Commons Attribution License, which permits unrestricted use, distribution, and reproduction in any medium, provided the original work is properly cited.

\begin{abstract}
Helicobacter pylori is recognized by the World Health Organization to be the primary cause of peptic ulcers, chronic gastritis, and stomach cancer, though the source of human infection is not well understood. One of the problems in understanding the source of human contamination is the difficulty in isolating the organism from the environment. However, the combination of PCR results with those of culturing of 471 drinking water samples can provide a more accurate picture of $H$. pylori detection. In this method 78 presumptive $H$. pylori colonies out of 266 tap water samples were obtained in the preliminary detection on modified Columbia agar (MCUA) slant relying on urease positivity with a rate of $29.3 \%$. However, only 11 out of them were confirmed by Gram staining and biochemical tests reducing the rate to $4.13 \%$ whereas only $3(1.46 \%)$ from 205 reverse osmosis (RO) water samples. Furthermore, only $6(54.5 \%)$ out of the 11 isolates from tap water and $1(33.3 \%)$ of the 3 RO isolates were confirmed by 16SrRNA PCR. Thus PCR confirmation reduced the rate to $2.2 \%$. In addition, only 4 (4\%) of 100 tap water samples negative for $H$. pylori by culture method were $H$. pylori positive by 16SrRNA. Water samples were collected from 24 districts of Basrah Governorate from February-December 2009. The direct recovery of $H$. pylori from drinking water is both alarming and scientifically exciting in terms of the investigation of its epidemiology.
\end{abstract}

\section{Introduction}

Helicobacter pylori is recognized as the major cause of gastritis and peptic ulcer and gastric mucosa-associated lymphoid tissue (MALT) gastric lymphoma [1]. The mechanism of $H$. pylori pathogenic effect is unclear but is believed to be related to host bacterial interactions initiated by virulence genes, and it is possible that these effects are enhanced by invasiveness of the bacterium [2-5]. H. pylori changes from the normal spiral-shaped bacillary form into the coccoid form when it is exposed to water or to other adverse conditions [6]. Hence attempts have been made to develop artificial media to achieve better culture recovery results than those obtained from traditional Columbia blood agar [7, 8]. Polymerase chain reaction (PCR) methods have also been used to detect $H$. pylori as its 16SrRNA gene sequence analysis unambiguously differentiated the Helicobacter genus from the closely related Campylobacter genus and other Helicobacter species
[9]. The presence of $H$. pylori in drinking water which was detected by PCR has been reported from several countries [10-12]. Hegarty et al. [13] also demonstrated the presence of respiring $H$. pylori from US surface water. The prevalence of disease attributed to $H$. pylori in Iraq is not available despite of its commonality.

Basrah Governorate, where Basrah city is located, has a population of about three millions; its water supply is mainly derived from three sources, Shatt-Al-Arab River, Tigris River, and Bada lake. Water from these sources is treated at 22 treatment works and distributed through approximately 13,000 Km pipe network.

Since the 1980s there has been a general marked deterioration in water quality in Iraq, reflecting the environmental degradation of the country caused by successive armed conflicts.

The aim of this study was isolating $H$. pylori from drinking water in Basrah, Iraq, on modified Columbia urea 
agar (MCUA) and HP media using MDCS method [7] and then confirming that by conventional biochemical tests and 16SrRNA PCR.

\section{Methods}

2.1. Sample Collection and Culturing. 266 samples of tap water and 205 samples from tankers supplying Reverse osmosis (RO) were collected from 24 districts covering more than $90 \%$ of Basrah Governorate during the period from February 2008 to December 2009. Samples of $500 \mathrm{~mL}$ water each were collected in sterile glass flasks and examined for chlorine concentration using $o$-toluidine. Samples were transferred within 1-2 hr. to the laboratory and filtered through $0.22 \mu \mathrm{m}$ Millipore filter membrane. Each membrane was then immersed into $2 \mathrm{~mL}$ of tryptic soy broth (TSB) for $1 \mathrm{~h}$. After that each $2 \mathrm{~mL}$ TSB was taken and placed at the lower portion of the slanted MCUA tube. Each tube was tilted a few times to allow the added broth to spread bacteria on the upper part of the slant. Slanted MCUA tube, was incubated microaerophically at $37^{\circ} \mathrm{C}$ for $1-2$ days, after which color changes from orange to pink in the solid phase, indicating urease activity. The resulting system is a simple monophasic-diphasic culture setup (MDCS), a diphasic solid liquid environment at the lower part of the test tube and a monophasic solid one above it [7]. From the bottom and the upper portions of the slanted MCUA tube subcultures were done on plates of MCUA and HP media for purification.

No controls were used in the isolation of the strains and also in PCR as they are out of reach for us in Iraq.

2.2. Primary Diagnosis of $H$. pylori. The suspected purified colonies were chosen according to the Gram staining and cultural characteristics.

2.3. Biochemical Tests. Biochemical tests include production of catalase, oxidase, urease, and $\mathrm{H}_{2} \mathrm{~S}$, nitrate reduction, growing in $3.5 \% \mathrm{NaCl}$, growing with $1 \%$ glycine, and growing at different temperatures.

2.4. Antibiotic Sensitivity Test. The method of Piddock [14] was used to test the sensitivity of 14 isolates of $H$. pylori from drinking water to seven types of antibiotics, kanamycin $30 \mu \mathrm{g}$, erythromycin $15 \mu \mathrm{g}$, tetracycline $30 \mathrm{mg}$, ampicillin $10 \mu \mathrm{g}$, rifampicin $5 \mu \mathrm{g}$, amoxicillin $30 \mu \mathrm{g}$ and gentamycin $30 \mu \mathrm{g}$ (Bioanalyse, Turkey).

2.5. 16SrRNA Identification of Isolates. All isolates from tap and RO water samples which gave positive results by biochemical tests as $H$. pylori and (100) samples which were $H$. pylori negative by culture method were further confirmed by using primers specifically designed for the identification of $H$. pylori based on 16SrRNA sequence [15]. The primers for 500 bp product of the 16SrRNA sequence are represented by the forward primer sequence: 5 GCT AAG AGA TCA GCC TAT GTC C3 and the reverse one: 5 TGG CAA TCA GCG TCA GGT AAT G3.
2.6. Preparation of Bacterial Genomic DNA. Genomic DNA from each isolate was prepared by vortex after suspending a loopful of colonies in $1 \mathrm{~mL}$ of phosphated-buffer saline (PBS) 7.6, centrifuging at $14000 \times \mathrm{g}$ for $2 \mathrm{~min}$, and boiling the pellet in $1 \mathrm{~mL}$ of distilled water for $1 \mathrm{~min}$ [16]. The samples were then centrifuged at $12000 \times \mathrm{g}$ for $4 \mathrm{~min}$ at $4^{\circ} \mathrm{C}$ and the supernatants were stored in sterile vials at $-70^{\circ} \mathrm{C}$ until they were used as PCR templates. Genomic DNA from water samples, which have been cultured but did not give isolates for $H$. pylori, were prepared by centrifuging $1 \mathrm{~mL}$ of the liquid portion of slant MCUA tube at $14000 \times \mathrm{g}$ for $2 \mathrm{~min}$ and washed with $1 \mathrm{~mL}$ of PBS to be completed by the same steps for $H$. pylori isolates. Concentration and purity were measured spectrophotometrically at $\mathrm{OD}_{260}$ and $\mathrm{OD}_{280}$ respectively, to exclude any possible contamination, and a gel of $0.8 \%$ agarose was used for electrophoresis.

2.7. PCR Amplification of $16 S r R N A$ for $H$. pylori. Amplification was carried out in a $25 \mu \mathrm{L}$ of reaction mixture containing $12.5 \mu \mathrm{L}$ master mix, $0.5 \mu \mathrm{L}$ forward primer, $0.5 \mu \mathrm{L}$ reverse primer, $5 \mu \mathrm{L}$ DNA samples, $6.5 \mu \mathrm{L}$ distilled water and $25 \mu \mathrm{L}$ mineral oil. PCR conditions for 16SrRNA include: denaturation step at $95^{\circ} \mathrm{C}$ for $5 \mathrm{~min}$, followed by 39 cycles at $94^{\circ} \mathrm{C}$ for $1 \mathrm{~min}$, annealing at $55^{\circ} \mathrm{C}$ for $1 \mathrm{~min}$ and extension at $72^{\circ} \mathrm{C}$ for $2 \mathrm{~min}$, and an additional extension step at $72^{\circ} \mathrm{C}$ for $7 \mathrm{~min}$. PCR products were electrophoresed in $2 \%$ agarose.

2.8. ureA Gene for $H$. pylori and PCR Amplification. All isolates which were confirmed by $16 \mathrm{SrRNA}$ have been tested for the presence of the ureA gene of $H$. pylori. The primer for $411 \mathrm{bp}$ product of the ureA sequence represented by the forward primer sequence: 5 GCC AAT GGT AAA GCC TTA GTT3 and the reverse one: 5 CTC CTT AAT TGT TTT TAC 3 [17]. Amplification was carried out in a $25 \mu \mathrm{L}$ of reaction mixture containing $12.5 \mu \mathrm{L}$ master mix, $0.5 \mu \mathrm{L}$ forward primer, $0.5 \mu \mathrm{L}$ reverse primer, $5 \mu \mathrm{L}$ DNA samples, $6.5 \mu \mathrm{L}$ distilled water and $25 \mu \mathrm{L}$ mineral oil. PCR conditions for ureA gene include: denaturation step at $95^{\circ} \mathrm{C}$ for $5 \mathrm{~min}$, followed by 35 cycles at $94^{\circ} \mathrm{C}$ for $1 \mathrm{~min}$, annealing at $45^{\circ} \mathrm{C}$ for. $1 \mathrm{~min}$ and, extension at $72^{\circ} \mathrm{C}$ for $1 \mathrm{~min}$ and an additional extension step at $72^{\circ} \mathrm{C}$ for $7 \mathrm{~min}$. PCR products were electrophoresed in $2 \%$ agarose.

\section{Results}

3.1. Culture Results. Out of 471 water samples, 14 (2.76\%) isolates of $H$. pylori were isolated from samples taken from 14 districts by culture method and identified by biochemical tests. They consist of $11(4.13 \%)$ H. pylori that have been isolated and diagnosed from 266 samples of tap water and 3 ones (1.46\%) from 205 RO samples.

The modified Columbia urea agar using MDCS method preliminarily revealed the presence of $H$. pylori in water samples, correlated with the change in the color of the slant MCUA tube from orange to pink that occurred at the same time thus giving an additional evidence for the presence of H. pylori in the samples (Figure 1). 
TABLE 1: Results of biochemical tests characterizing $H$. pylori isolates from 14 districts.

\begin{tabular}{|c|c|c|c|c|c|c|c|c|c|}
\hline District no & Catalase & Oxidase & Urease & $\begin{array}{l}\text { Nitrate } \\
\text { reduction }\end{array}$ & $\mathrm{H}_{2} \mathrm{~S}$ & $\begin{array}{c}\text { Growth with } \\
3.5 \% \mathrm{NaCl}\end{array}$ & $\begin{array}{l}\text { Growth on } 1 \% \\
\text { glycin }\end{array}$ & $\begin{array}{c}\text { Growth at } \\
42^{\circ} \mathrm{C}\end{array}$ & $\begin{array}{l}\text { Growth at } \\
25^{\circ} \mathrm{C}\end{array}$ \\
\hline 1 & + & + & + & - & - & - & - & - & - \\
\hline 2 & + & + & + & - & - & - & - & + & - \\
\hline 3 & + & + & + & + & - & - & - & - & - \\
\hline 4 & + & + & + & - & - & - & - & - & - \\
\hline 5 & + & + & + & - & - & - & - & + & - \\
\hline 6 & + & + & + & + & - & - & - & - & - \\
\hline 7 & + & + & + & - & - & - & - & - & - \\
\hline 8 & + & + & + & - & - & - & - & - & - \\
\hline 9 & + & + & + & - & - & - & - & - & - \\
\hline 10 & + & + & + & - & - & - & - & - & - \\
\hline 11 & + & + & + & + & - & - & - & - & - \\
\hline 12 & + & + & + & - & - & - & - & - & - \\
\hline 13 & + & + & + & - & - & - & - & - & - \\
\hline 14 & + & + & + & - & - & - & - & - & - \\
\hline
\end{tabular}

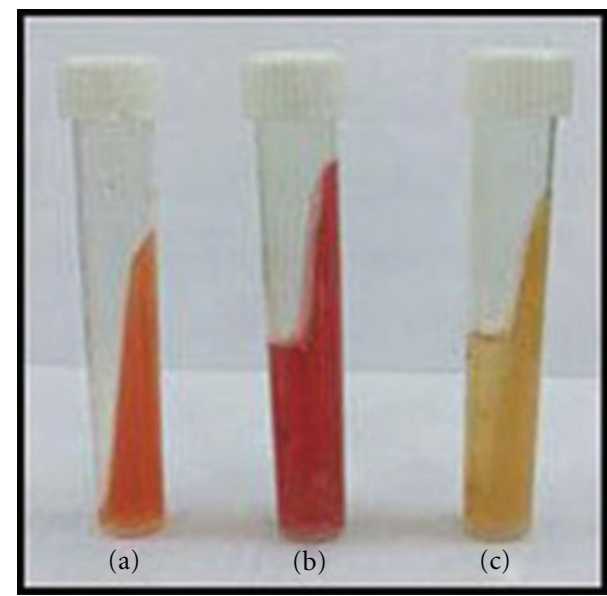

FIGURE 1: Change in color of slant MCUA tube, (a) slant MCUA tube only, (b) positive slant MCUA tube, culture, (c) negative slant MCUA tube, culture.

The isolation rate upon subculturing on HP medium was $14 / 471(2.76 \%)$ isolates of $H$. pylori, while on MCUA medium was $6 / 471(1.2 \%)$ isolates included in the 14 isolates of H. pylori.

On MCUA medium, the colonies of the isolated H. pylori were small to middle in size, rounded, and creamy in color, while, on HP medium, the isolated $H$. pylori were small in size, rounded, and transparent. Both the MCUA and HP media showed change in color from yellow/orange to red.

All H. pylori isolates were Gram-negative spiral to coccobacilli and shared the characteristic catalase, urease, and oxidase production, but differ slightly with respect to other tests (Table 1). Collectively, 3 isolates are being positive in nitrate reduction, 2 in being able to grow at $42^{\circ} \mathrm{C}$, and 9 negatives in both traits.

3.2. Antibiotics Susceptibility. For H. pylori isolates from drinking water, tetracycline was found to be the most

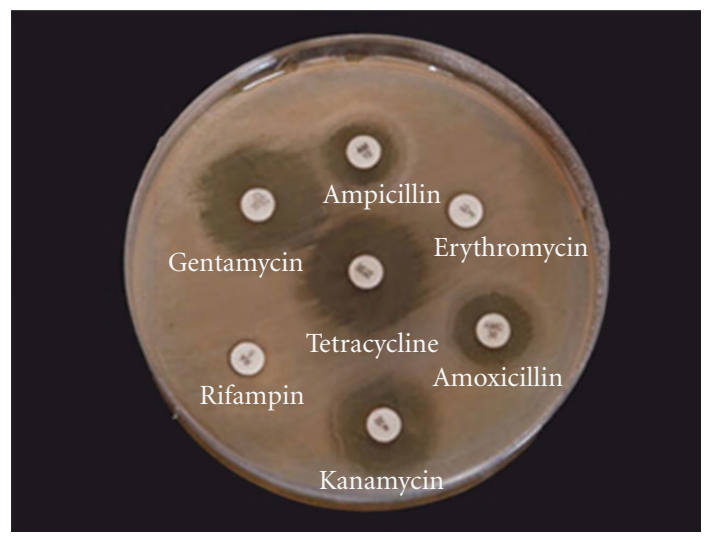

Figure 2: Antibiotic effects on $H$. pylori isolated from drinking water.

effective antibiotic, $71 \%$ of the tested isolates were sensitive to tetracycline followed by kanamycin $57 \%$ and gentamycin $36 \%$, ampicillin $14 \%$. Rifampicin and amoxicillin were shown to be the least effective ones $(7 \%)$ against $H$. pylori isolated from drinking water,while erythromycin was a non effective antibiotic, as shown in (Figure 2) and in reference to interpretive chart of zone sizes.

3.3. PCR Results. Only 6 out of $11(54.5 \%)$ H. pylori morphologically and biochemically identified isolates from tap water were found to harbor 16SrRNA gene and of the 3 R.O isolates only one $(33.3 \%)$ isolate gave positive results for 16 SrRNA gene by PCR. Thus leaving out $50 \%$ of the conventionally identified isolates as false positive. From the100 samples negative for $H$. pylori by culturing, only 4 (4\%), gave positive results for $16 \mathrm{SrRNA}$.

PCR products for 16SrRNA based primers gave bands on agarose gel corresponding to a 500 base pair product 


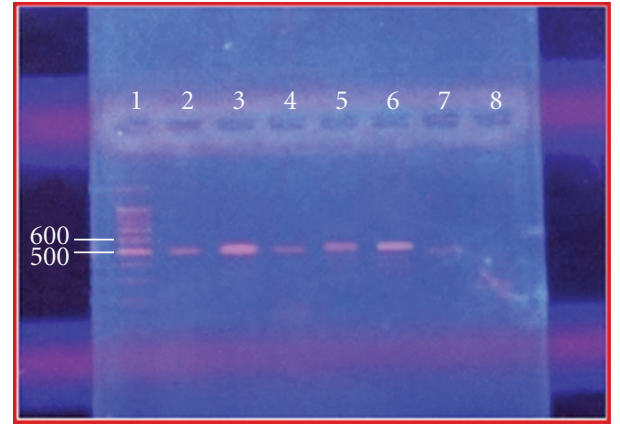

FIgURe 3: PCR products for 16SrRNA-based primers gave band on agarose gel corresponding to a 500 base pair product when compared to the molecular ladder. Lane 1, molecular ladder (1500100) bp, lane (2-6) bands of PCR products for H. pylori with 16SrRNA.

when compared to the molecular ladder, thus identifying the isolates as H. pylori as shown in (Figure 3).

3.4. ureA Gene for $H$. pylori and PCR Amplification. All isolates of $H$. pylori which have been confirmed by 16SrRNA, did not give specific results to ureA (Figure 4), only products of $100 \mathrm{bp}$ have been obtained and also a much larger bands.

\section{Discussion}

Natural habitat of $H$. pylori is in the human stomach, other sources of $H$. pylori and its mode of transmission are unknown [18]. In this study, H. pylori has been isolated and diagnosed from drinking water by culture method and a combination of biochemical and PCR test. The first indication for the presence of $H$. pylori in water came from AL-Sulami et al. [8] in which 10 isolates were identified as $H$. pylori by biochemical tests. That finding has been confirmed by current study using the same method and a combination of conventional and PCR tests in identifying recovered $H$. pylori.

A low recovery of a pathogen is not surprising considering various factors affecting its survival in water. Upon primary, isolation there were 78 urease-positive isolates obtained from 266 tap water samples and 43 urease-positive ones from RO water samples. The numbers were reduced to 11 and 3 isolates, respectively, after subjecting them to conventional tests leaving 67 and 40 false-positive ones. Urease-negative isolates were not considered. Other bacteria were mainly pseudomonads.

So far there is no published paper proving the viability of coccoid form or the possibility that coccoid form transforms to spiral bacillary form. Our results indicate that some $H$. pylori are still viable and appear as spiral bacillary after Gram staining smears from colonies on MCUA; others are not and only can be detected by PCR.

Based on the assumption that all $H$. pylori in drinking water are coccoid [6], the results implicitly indicate the

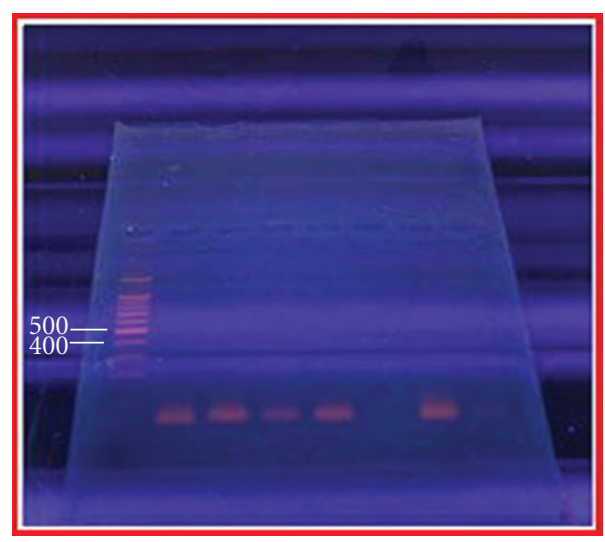

FIGURE 4: PCR product for $H$. pylori with ureA gene based primers. Lane 1, molecular ladder (1500-100) bp, no band of PCR product for $H$. pylori with ureA gene have been obtained.

possibility of the transformation of some coccoid form to spiral bacillary form.

It is difficult to compare our data with those published, because each author has used a distinct method to detect the bacterium, and all attempts to culture the organism directly from water samples $[18,19]$ have been unsuccessful. This may be due to the fact that overgrowth by other microorganisms on the rich media led to the difficulty of isolation of $H$. pylori from water, and another reason for the lack of recovery of $H$. pylori from the environment is the fastidious nature of $H$. pylori which has a polymorphisms phenomenon. Under these circumstances, the organism would not be recovered by traditional culture techniques; hence in our study we developed a different protocol for culturing $H$. pylori from water. The importance of this method is to provide a possibility of successful culture method for $H$. pylori.

In general, high-resistance profile to the tested antibiotics is apparent on these isolates as indicated by $H$. pylori resistance for tetracycline in $29 \%$ of the isolates, also in case of kanamycin $H$. pylori resistance of $43 \%$ which is less than Al-Sulami et al. [8] result of $60 \%$. Amoxicillin which represents active antibiotics in treatment of this bacterium was ineffective with a resistance in $93 \%$ of the isolates.

4.1. 16SrRNA for $H$. pylori Detection by PCR. In this study, this is the first report on using 16SrRNA amplification and confirmation of $H$. pylori isolates from environmental samples in Iraq. The 16SrRNA was chosen for detection of $H$. pylori because it exhibits a high degree of functional and evolutionary homology within all bacteria [9]. Only 7 isolates, out of 14 morphologically and biochemically identified $H$. pylori, were confirmed by 16SrRNA as they gave positive results for $16 \mathrm{SrRNA}$. The prevalence of false positive isolates by conventional tests indicates a nonspecific approach. Meanwhile, in 100 drinking water samples in which no $H$. pylori was detected by culture method, 4 samples produced positive results by $16 \mathrm{SrRNA}$. This means that cells of $H$. pylori that are not detected by culture method 
can be done by PCR, and hence, the MDCS provides the opportunity for simultaneous detection of both culturable and nonculturable forms.

Results of PCR products of 16SrRNA gene amplification revealed the presence of 500 base pair sequence of the gene coded the 16SrRNA molecule, and this result agrees with that of [15]. The size of PCR product was determined by comparing it with a DNA ladder, which contains DNA fragments of known size (1500-100) base pairs. Our results may shed additional light on the evidence supporting waterborne transmission which emanates from the fact that there is a direct recovery of $H$. pylori from tap water and R.O water concomitantly confirmed by PCR.

4.2. ureA Gene for H. pylori Detection by PCR. The ureA genotype was expected to be present in all Helicobacter positive strains. However, our study was unable to detect the ureA gene in the isolates of $H$. pylori already confirmed by 16SrRNA. This result agrees with Tiveljung et al. [20] who used ureA gene and were unable to detect it in $H$. pylori strain regarded as normal control.

\section{Conclusion}

The isolation of $H$. pylori from drinking water, tap and R.O, by culture method and consequent identification by biochemical tests and PCR represents a clear signal for the presence of this dangerous but illusive pathogen in our consumable water. It, certainly, will impact our search for a better epidemiological understanding and measures of control.

\section{References}

[1] J. C. Atherton, "The pathogenesis of Helicobacter pyloriinduced gastro-duodenal diseases," Annual Review of Pathology, vol. 1, pp. 63-96, 2006.

[2] Y. Elitsur and J. Yahav, "Helicobacter pylori infection in pediatrics," Helicobacter, Supplement, vol. 10, no. 1, pp. 47-53, 2005.

[3] A. Dubois and T. Boren, "Helicobacter pylori is invasive and it may be a facultative intracellular organism," Cellular Microbiology, vol. 9, no. 5, pp. 1108-1116, 2007.

[4] M. R. Amieva and E. M. El-Omar, "Host-Bacterial Interactions in Helicobacter pylori Infection," Gastroenterology, vol. 134, no. 1, pp. 306-323, 2008.

[5] V. Necchi, M. E. Candusso, F. Tava et al., "Intracellular, intercellular, and stromal invasion of gastric mucosa, preneoplastic lesions, and cancer by Helicobacter pylori," Gastroenterology, vol. 132, no. 3, pp. 1009-1023, 2007.

[6] N. F. Azevedo, C. Almeida, L. Cerqueira, S. Dias, C. W. Keevil, and M. J. Vieira, "Coccoid form of Helicobacter pylori as a morphological manifestation of cell adaptation to the environment," Applied and Environmental Microbiology, vol. 73, no. 10, pp. 3423-3427, 2007.

[7] A. A. Al-Sulami, H. S. Al-Kiat, L. K. Bakker, and H. Hunoon, "Primary isolation and detection of Helicobacter pylori from dyspeptic patients: a simple, rapid method," Eastern Mediterranean Health Journal, vol. 14, no. 2, pp. 268-275, 2008.
[8] A. A. Al-Sulami, A. M. R. Al-Taee, and M. G. Juma'a, "Isolation and identification of Helicobacter pylori from drinking water in Basra governorate, Iraq," Eastern Mediterranean Health Journal, vol. 16, no. 9, pp. 810-816, 2010.

[9] H. Liu, A. Rahman, C. Semino-Mora, S. Q. Doi, and A. Dubois, "Specific and sensitive detection of H. pylori in biological specimens by real-time RT-PCR and in situ hybridization," PLoS ONE, vol. 3, no. 7, Article ID e2689, 2008.

[10] K. Hulten, S. W. Han, H. Enroth et al., "Helicobacter pylori in the drinking water in Peru," Gastroenterology, vol. 110, no. 4, pp. 1031-1035, 1996.

[11] J. A. Benson, K. A. Fode-Vaughan, and M. L. P. Collins, "Detection of Helicobacter pylori in water by direct PCR," Letters in Applied Microbiology, vol. 39, no. 3, pp. 221-225, 2004.

[12] M. Mazari-Hiriart, Y. López-Vidal, and J. J. Calva, "Helicobacter pylori in water systems for human use in Mexico City," Water Science and Technology, vol. 43, no. 12, pp. 93-98, 2001.

[13] J. P. Hegarty, M. T. Dowd, and K. H. Baker, "Occurrence of Helicobacter pylori in surface water in the United States," Journal of Applied Microbiology, vol. 87, no. 5, pp. 697-701, 1999.

[14] L. J. V. Piddock, "A review techniques used for the determination of antimicrobial resistance and sensitivity in bacteria," Journal of Applied Bacteriology, vol. 68, no. 4, pp. 307-318, 1990.

[15] T. Falsafi, R. Favaedi, F. Mahjoub, and M. Najafi, "Application of stool-PCR test for diagnosis of Helicobacter pylori infection in children," World Journal of Gastroenterology, vol. 15, no. 4, pp. 484-488, 2009.

[16] R. M. Peek Jr., G. G. Miller, K. T. Tham et al., "Detection of Helicobacter pylori gene expression in human gastric mucosa," Journal of Clinical Microbiology, vol. 33, no. 1, pp. 28-32, 1995.

[17] M. Notarnicola, F. Russo, A. Cavallini et al., "PCR identification of Helicobacter pylori DNA in faeces from patients with gastroduodenal pathology," Medical Science Research, vol. 24, no. 11, pp. 785-787, 1996.

[18] N. F. Azevedo, C. Almeida, I. Fernandes et al., "Survival of gastric and enterohepatic Helicobacter spp. in water: implications for transmission," Applied and Environmental Microbiology, vol. 74, no. 6, pp. 1805-1811, 2008.

[19] M. S. Giao, N. F. Azevedo, S. A. Wilks, M. J. Vieira, and C. W. Keevil, "Persistence of Helicobacter pylori in heterotrophic drinking-water biofilms," Applied and Environmental Microbiology, vol. 74, no. 19, pp. 5898-5904, 2008.

[20] A. Tiveljung, K. Borch, J. Jonasson, S. Mårdh, F. Petersson, and H. J. Monstein, "Identification of Helicobacter in gastric biopsies by PCR based on $16 \mathrm{~S}$ rDNA sequences: a matter of little significance for the prediction of $H$. pylori-associated gastritis?" Journal of Medical Microbiology, vol. 47, no. 8, pp. 695-704, 1998. 


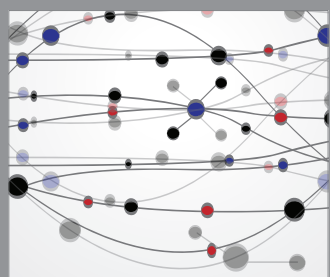

The Scientific World Journal
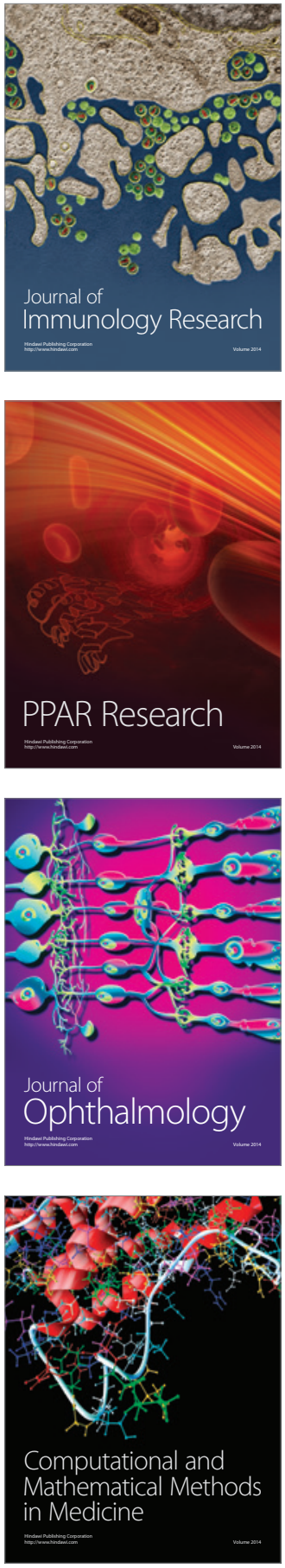

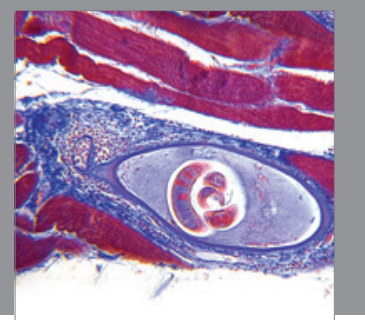

Gastroenterology

Research and Practice
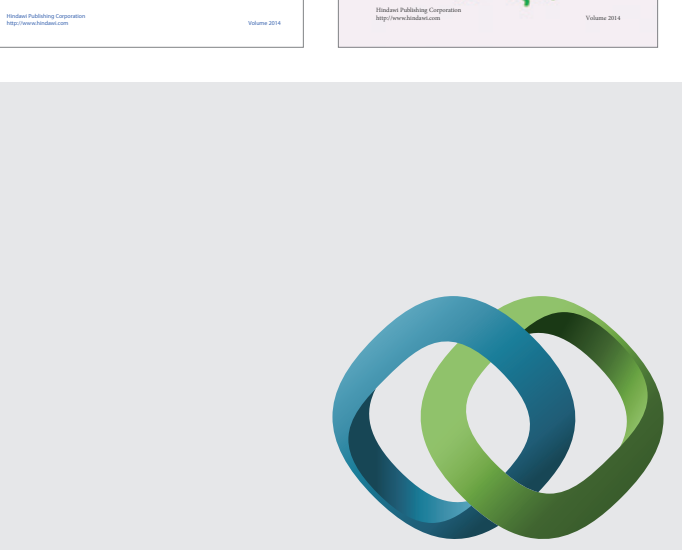

\section{Hindawi}

Submit your manuscripts at

http://www.hindawi.com
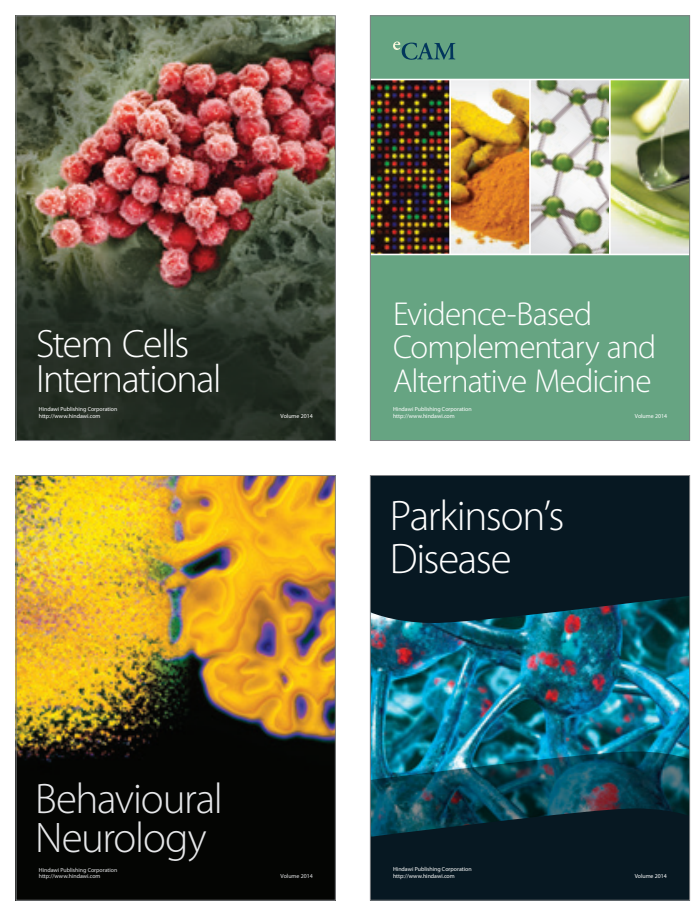

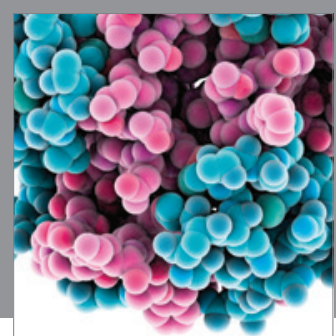

Journal of
Diabetes Research

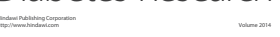

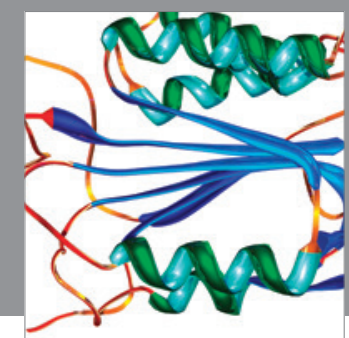

Disease Markers
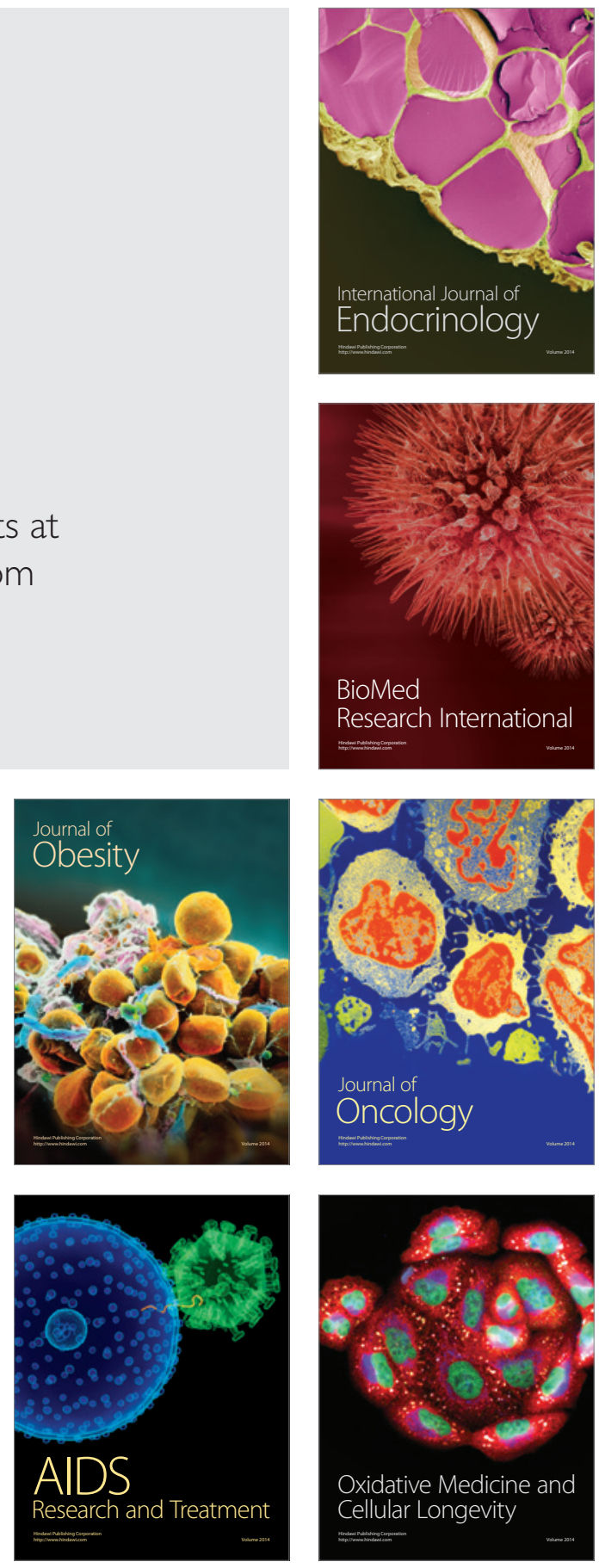